\title{
Growth and Development of the Thyroidectomized Ovine Fetus
}

\author{
A. ERENBERG, K. OMORI, J. H. MENKES, W. OH, AND D. A. FISHER ${ }^{(43)}$ \\ Department of Pediatrics, UCLA-Harbor General Hospital, Torrance, and \\ UCLA School of Medicine, Los Angeles, California, USA
}

Extract

Thyroidectomies were performed through a flank incision and uterotomy on five fetuses of 1-4-year-old Columbia and Columbia Suffolk date-bred ewes of 90-110 days gestation. The fetuses were killed 19-43 days post-thyroidectomy. Body and organ weights, limb roentgenograms, DNA, RNA, and protein concentrations of selected tissues, cerebral and cerebellar lipid concentrations, and cerebellar cerebroside fatty acid composition were measured and compared with similar measurements in control animals. In the thyroidectomized fetuses mean carcass and lung weights were significantly reduced and wool development was consistently delayed. Extremity $x$-rays showed a delay in the time of appearance and a decrease in the size of epiphyseal centers. The mean DNA concentration was low in muscle tissue; mean protein concentrations were reduced in cerebellum, heart, lung, thymus, and muscle tissues, while mean total lipid concentration was low in cerebral tissue; the percentage of 18-carbon fatty acids was significantly increased in cerebellar cerebrosides. These results indicate that thyroid hormone deficiency, present during the last trimester of gestation in the ovine fetus, impairs carcass and lung growth, delays bone and skin maturation, inhibits growth in cell size in heart, lung, thymus, and cerebral tissues, and delays myelination in the central nervous system (CNS).

\section{Speculation}

The present results, considered with results of other investigations of the effects of thyroid hormone deficiency in fetal and newborn mammals, indicate that hypothyroidism impairs somatic growth, delays bone growth and maturation, delays cell growth and replication in the CNS, and inhibits CNS myelination. The critical period for these effects varies in different species. In the rat this period is postnatal, whereas in the sheep it extends into the third trimester of pregnancy. During pregnancy, carcass growth, bone maturation, and lung maturation are most affected in the sheep; CNS changes are minimal. In man fetal hypothyroidism may produce some delay in bone maturation but somatic growth retardation and signs and symptoms of hypothyroidism are not usually present at birth. Moreover, as in the sheep, any delay in CNS maturation probably is minimal in utero, since very early postnatal treatment minimizes mental retardation. Thus early diagnosis and treatment of hypothyroidism is necessary and consideration of the possibility of newborn screening would seem appropriate.

It is well known that the athyrotic human fetus at birth shows no evidence of somatic growth retardation, although osseous development may be retarded (2). In addition, it has been established in a number of species, including man, that piacental transfer of iodothyronines is minimal $(11,12,17$,
$19,23)$. Therefore, it is possible that thyroid hormones are not necessary for normal fetal somatic growth. The effect of intrauterine hypothyroidism on CNS growth and maturation also is not entirely clear. Thus we have conducted studies of body and organ growth and thyroid hormone kinetics in the fetal sheep after thyroidectomy. The kinetic studies, described elsewhere (14), indicated that fetal serum levels of both thyroxine $\left(\mathrm{T}_{4}\right)$ and triiodothyronine $\left(\mathrm{T}_{3}\right)$ are unmeasurable soon after fetal thyroidectomy and that the athyrotic fetus receives minimal quantities of maternal thyroid hormones across the placenta. The present report includes data regarding the effects of fetal thyroidectomy on somatic and organ growth, on RNA, DNA, and protein concentration of various organs, and on brain lipid concentration and composition.

\section{MATERIALS AND METHODS}

Columbia and Columbia Suffolk date-bred ewes, $1-4$ years old, were obtained from a local source, maintained at environmental temperatures of $57-85^{\circ} \mathrm{F}$, and given free access to alfalfa and water. Under spinal anesthesia through a flank incision uterotomy was performed on five ewes of $90-110$ days gestation. Four of these were carrying singleton fetuses; one was carrying a twin fetus. No more than three cotyledons were lost at the time of surgery. The fetal neck was isolated, exposed, and thyroidectomy performed. Four animals had repeat uterotomies performed 25-30 days post-thyroidectomy for catheter placement. Maternal and fetal blood oxygenation and $\mathrm{pH}$ were monitored during surgery and remained normal. All ewes were feeding within 2 hours of completion of surgery and maintained their weight and general health postoperatively. Between 119 and 140 days gestation (19-43 days post-thyroidectomy) the five animals were killed and an autopsy performed on each fetus. After weighing each organ, the tissue was quick-frozen and stored at $-4^{\circ}$. Body and organ weights of selected organs were plotted against normal values derived from 60 ovine fetuses, the gestational ages of which ranged from 90 to 150 days and on which surgical procedures had been performed for various reasons (31); none was performed for the purpose of inducing intrauterine growth retardation. The RNA, DNA, and protein concentration of muscle, liver, spleen, kidney, heart, cerebrum, cerebellum, thymus, and lung tissue of the thyroidectomized fetuses were compared with similar data obtained from eight control singleton fetuses which were matched for gestational age ( \pm 3 days) and sex at the time of killing. The weight of the control fetuses fell within the $1 \mathrm{SD}$ range for age of the larger group of 60 normal fetuses. Roentgenograms of all four extremities were taken soon after killing and compared with films obtained from control fetuses of similar gestational age. Tissue protein was determined by the method of Lowry et al. (28), DNA by the method of Burton (7), and RNA by the method of Webb (39). Serum $\mathrm{T}_{4}$ and $\mathrm{T}_{3}$ concentrations were 
measured by radioimmunoassay (RIA) methods developed in our laboratories $(9,10)$. Serum thyroid-stimulating hormone (TSH) was measured in a heterologous RIA using a bovine TSH antiserum, labeled bovine TSH, and an ovine TSH standard (NIH-S6). The method is similar to that of Reichlin et al. (34).

Cerebral and cerebellar lipids were extracted with 20 volumes chloroform-methanol $(2 / 1, v / v)$. The extract was washed with 0.2 volume water and the organic phase evaporated to dryness. Total lipid content was determined gravimetrically on aliquots using a Kahn microbalance. The dried lipids were taken up in chloroform and separated into their major classes by thin layer chromatography using chloroform-methanol-water $(65 / 25 / 4, \mathrm{v} / \mathrm{v} / \mathrm{v})$ as the developing solvent. Total lipid phosphorus was determined by the method of Bartlett (6) and cholesterol by the method of Friede and $\mathrm{Hu}(18)$. Cerebrosides and sulfatides, as separated by thin layer chromatography, were quantitated by their hexose content as described in a previous publication (15).

Cerebroside fatty acid methyl esters were obtained by methanolysis of cerebrosides in dry hydrochloric acid as described by Stein et al. (36). The fatty acid methyl esters were assayed by gas-liquid chromatography using a Barber Coleman 5001 gas chromatography apparatus and a column of acid-washed Chromosorb W (80-100 mesh) as support and $15 \%$ diethylene glycol succinate as stationary phase. The column was operated at $200^{\circ}$ and 15 pounds argon pressure. Known fatty acid standards were analyzed simultaneously.

\section{RESULTS}

Table 1 lists the estimated gestational age at the time of thyroidectomy and estimated gestational age, fetal weight, and fetal serum $T_{4}$ and $T_{3}$ concentrations at autopsy 19-43 days after thyroidectomy. There was a fall in serum $T_{4}$ levels from a mean of $12 \mu \mathrm{g} / 100 \mathrm{ml}$ at the time of thyroidectomy to a mean of less than $0.7 \mu \mathrm{g} / 100 \mathrm{ml}$ at the time of autopsy. Serum $\mathrm{T}_{3}$ levels were unmeasurable before and after thyroidectomy. Serum TSH concentrations rose from control values of less than $10 \mu \mathrm{U} / \mathrm{ml}$ to values of 300 to $1500 \mu \mathrm{U} / \mathrm{ml}$ at the time of killing. There was no remaining thyroid tissue in any fetus at autopsy by gross inspection.

Table 1. Gestational age, body weight, serum thyroxine, and serum TSH concentrations in thyroidectomized fetuses ${ }^{1}$

\begin{tabular}{|c|c|c|c|c|c|c|}
\hline \multirow[b]{2}{*}{ Sheep } & \multirow{2}{*}{$\begin{array}{l}\text { Estimated gestational } \\
\text { age at thyroidectomy, } \\
\text { days }\end{array}$} & \multicolumn{5}{|c|}{ At time of killing } \\
\hline & & $\begin{array}{c}\text { Gestational } \\
\text { age, days }\end{array}$ & $\begin{array}{l}\text { Weight, } \\
\mathrm{kg}\end{array}$ & $\begin{array}{c}\mathrm{T}_{4} \text { conc. } \\
\mu \mathrm{g} / 100 \mathrm{ml}^{1}\end{array}$ & $\begin{array}{c}\text { Serum } \mathrm{T}_{3} \text { conc. } \\
\mathrm{ng} / 100 \mathrm{ml}\end{array}$ & $\begin{array}{c}\text { TSH conc. } \\
\mu \mathrm{U} / \mathrm{ml}^{3}\end{array}$ \\
\hline$T-4$ & 100 & 119 & 1.48 & $<0.7$ & $<18$ & 300 \\
\hline$T-14$ & 97 & 130 & 1.53 & $<0.7$ & $<18$ & 475 \\
\hline$T-19$ & 90 & 133 & 1.96 & $<0.7$ & $<18$ & 1500 \\
\hline$T-20$ & 95 & 138 & 2.58 & $<0.7$ & $<18$ & \\
\hline$T-21$ & 110 & 140 & 2.45 & $<0.7$ & $<18$ & 540 \\
\hline
\end{tabular}

${ }^{1} \mathrm{~T}_{4}$ : thyroxine; $\mathrm{T}_{3}$ : triiod o thyronine; $\mathrm{TSH}$ : thy roid-stimulating hormone.

${ }^{2}$ Normal range $4.5-12 \mu \mathrm{g} / 100 \mathrm{ml}$.

${ }^{3}$ Normal range $<20 \mu \mathrm{U} / \mathrm{ml}$.
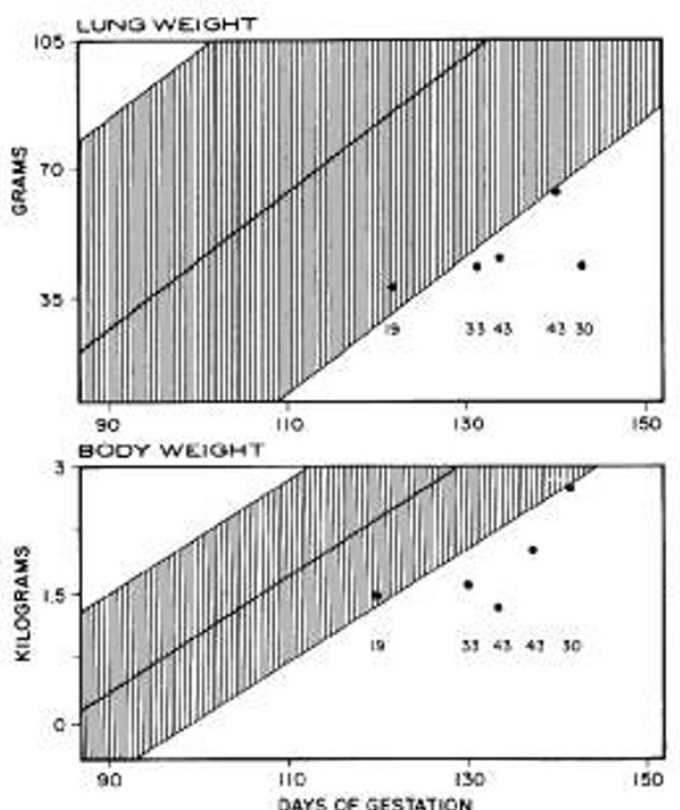

Fig. 1. Body weights and lung weights of the 5 thyroidectomized fetuses plotted versus the weight range of 60 normal fetuses of $90-150$ days gestation. Shaded area: normal range ( \pm 2 SD). Number below each point: number of days from thyroidectomy to autopsy of the experimental animals.

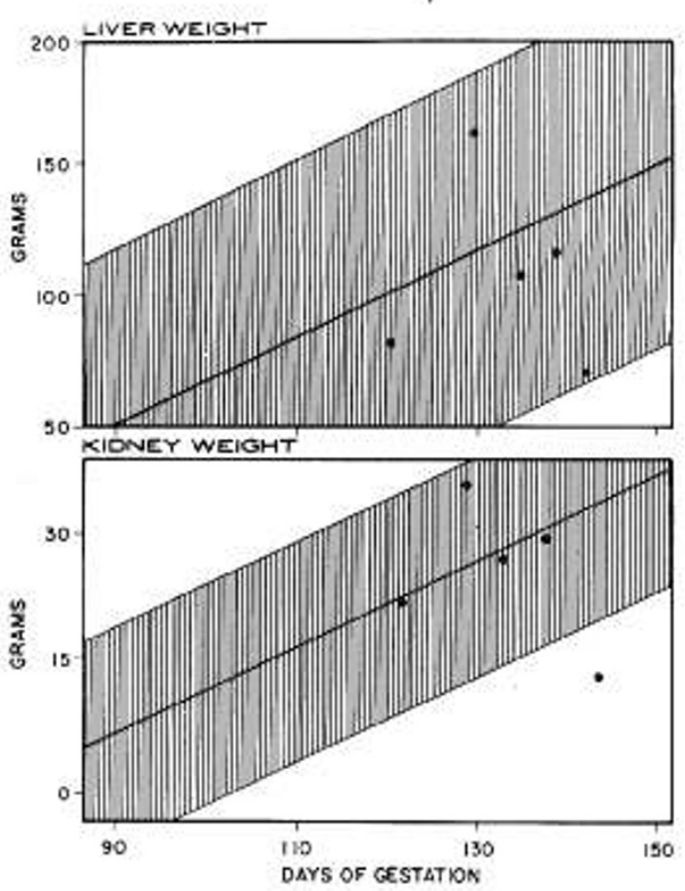

Fig. 2. Liver and kidney weights of the 5 thyroidectomized fetuses plotted versus the weight range of 60 normal fetuses of $90-150$ days gestation. Shaded area: normal range ( \pm 2 SD). 
Figures 1, 2, and 3 show the body weights, lung weights, liver weights, kidney weights, brain weights, and heart weights of the thyroidectomized fetuses plotted relative to the $2 \mathrm{SD}$ range of the 60 normal fetuses of $90-150$ days gestation (31). The thyroidectomized fetuses lacked normal wool development, striated muscle seemed friable at autopsy, and there was a paucity of subcutaneous fat. All fetuses tended to be small; however, the body weights of two fell into the low normal range. All organ weights were within the normal range except for the lungs.

Table 2 presents the wet weight, RNA and DNA content, protein to DNA ratio, and protein concentration data for various organs of the five thyroidectomized and eight control fetuses. The lungs were the only organs whose mean weight fell outside the normal range; however, muscle mass was not weighed. The RNA concentrations of respective tissues were similar in thyroidectomized and control fetuses. The mean DNA concentration was reduced only in muscle of the thyroidectomized animals. Mean protein concentrations were reduced in cerebellum, heart, lung, thymus, and muscle tissues of thyroidectomized as contrasted with control fetuses. The mean protein to DNA ratio was significantly reduced only in lung tissue of thyroidectomized fetuses.

Carcass weights were calculated by subtracting the organ weights from total body weight and assuming that relative intestine weights were similar in the fetuses studied. The mean calculated carcass weight was significantly less in the thyroidectomized fetuses than in controls $(1.76 \mathrm{~kg} \pm 0.22$ versus 2.50 $\mathrm{kg} \pm 0.33, P<0.05)$. Mean measured body lengths and the mean forefoot and hindfoot lengths were similar in thyroidectomized and control fetuses.

Figure 4 shows representative $x$-rays of the extremities from a thyroidectomized fetus $(B)$ for comparison with similar $\mathrm{x}$-rays from the control euthyroid twin $(A)$. The extremity $\mathrm{x}$-rays of the thyroidectomized fetuses consistently showed a delay in the time of appearance of epiphyseal centers, a

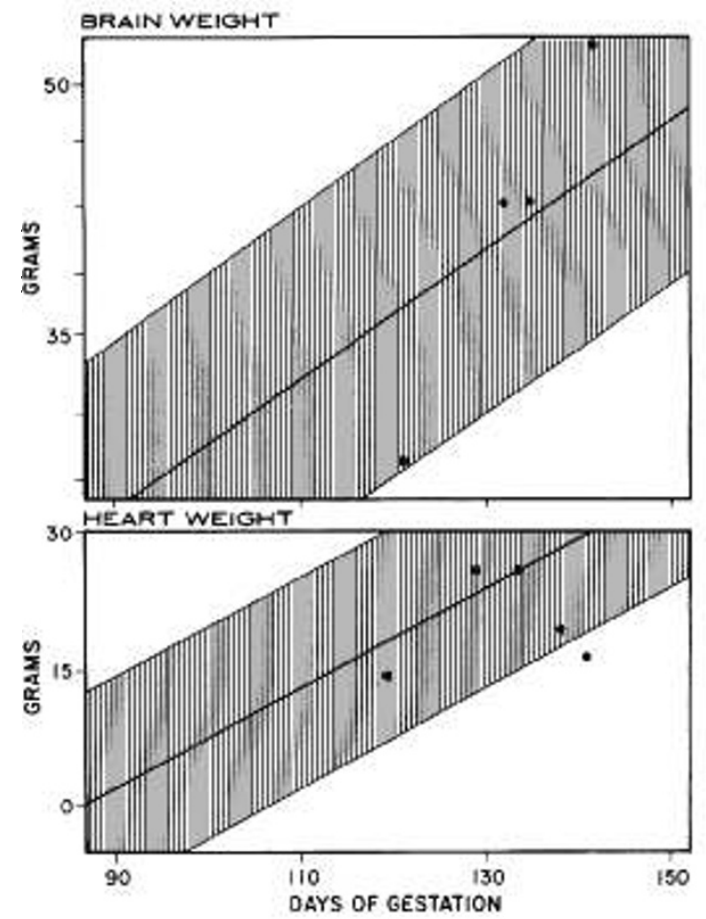

Fig. 3. Brain and heart weights of the 5 thyroidectomized fetuses plotted versus the weight range of 60 normal fetuses of $90-150$ days gestation. Shaded area: normal range $( \pm 2 \mathrm{SD})$.

Table 2. Wet weights, RNA, DNA, and protein concentrations of selected organs or tissues of thyroidectomized ovine fetuses and control fetuses matched for sex and gestational age $e^{1}$

\begin{tabular}{|c|c|c|c|c|c|}
\hline & Wet weight, g & RNA, mg/g & DNA, $\mathrm{mg} / \mathrm{g}$ & Protein, $\mathrm{mg} / \mathrm{g}$ & Protein/DNA \\
\hline \multicolumn{6}{|c|}{ Cerebellum } \\
\hline $\mathrm{Tx}$ & $4.7 \pm 0.9$ & $2.9 \pm 0.4$ & $10.1 \pm 2.4$ & $123 \pm 13^{2}$ & $12.9 \pm 4.7$ \\
\hline $\mathrm{C}$ & $4.2 \pm 0.5$ & $3.1 \pm 0.9$ & $11.0 \pm 2.1$ & $189 \pm 20$ & $17.2 \pm 2.2$ \\
\hline \multicolumn{6}{|c|}{ Cerebrum } \\
\hline $\mathrm{Tx}$ & $36.3 \pm 4.4$ & $3.8 \pm 0.8$ & $2.1 \pm 0.2$ & $148 \pm 20$ & $75.4 \pm 15.1$ \\
\hline $\mathrm{C}$ & $39.4 \pm 3.0$ & $3.0 \pm 0.5$ & $4.2 \pm 2.5$ & $168 \pm 27$ & $47.7 \pm 14.2$ \\
\hline \multicolumn{6}{|c|}{ Heart } \\
\hline$T x$ & $17.8 \pm 2.0$ & $7.8 \pm 0.4$ & $10.2 \pm 0.8$ & $276 \pm 20^{2}$ & $27.5 \pm 2.2$ \\
\hline $\mathrm{C}$ & $26.1 \pm 4.9$ & $6.6 \pm 0.9$ & $10.7 \pm 1.3$ & $365 \pm 30$ & $32.8 \pm 2.9$ \\
\hline \multicolumn{6}{|c|}{ Kidneys } \\
\hline$T x$ & $22.5 \pm 4.6$ & $4.9 \pm 0.6$ & $17.4 \pm 2.0$ & $260 \pm 39$ & $15.9 \pm 3.1$ \\
\hline $\mathrm{C}$ & $22.8 \pm 2.5$ & $4.6 \pm 0.6$ & $16.5 \pm 1.8$ & $234 \pm 14$ & $14.9 \pm 2.3$ \\
\hline \multicolumn{6}{|l|}{ Liver } \\
\hline $\mathrm{Tx}$ & $101.0 \pm 16.0$ & $8.3 \pm 1.4$ & $16.6 \pm 1.0$ & $303 \pm 50$ & $18.2 \pm 3.6$ \\
\hline $\mathrm{C}$ & $112.0 \pm 17.0$ & $8.4 \pm 1.6$ & $12.7 \pm 1.9$ & $368 \pm 50$ & $31.7 \pm 7.7$ \\
\hline \multicolumn{6}{|l|}{ Lung } \\
\hline Tx & $48.0 \pm 4.0^{2}$ & $6.9 \pm 1.6$ & $33.6 \pm 6.1$ & $182 \pm 11^{2}$ & $6.1 \pm 1.0^{2}$ \\
\hline $\mathrm{C}$ & $98.0 \pm 14.0$ & $5.6 \pm 0.4$ & $24.3 \pm 5.1$ & $260 \pm 29$ & $12.5 \pm 2.8$ \\
\hline \multicolumn{6}{|c|}{ Spleen } \\
\hline $\mathrm{Tx}$ & $5.3 \pm 0.6$ & $10.7 \pm 3.6$ & $26.0 \pm 2.2$ & $435 \pm 50$ & $12.3 \pm 1.2$ \\
\hline $\mathrm{C}$ & $6.6 \pm 1.4$ & $5.6 \pm 1.1$ & $28.0 \pm 4.0$ & $406 \pm 30$ & $16.0 \pm 2.2$ \\
\hline \multicolumn{6}{|c|}{ Thymus } \\
\hline $\mathrm{Tx}$ & $8.1 \pm 1.0$ & $7.8 \pm 1.2$ & $50.9 \pm 18.5$ & $176 \pm 24^{2}$ & $4.4 \pm 2.2$ \\
\hline $\mathrm{C}$ & $8.6 \pm 2.2$ & $7.8 \pm 0.7$ & $58.4 \pm 14.3$ & $282 \pm 13$ & $5.8 \pm 2.4$ \\
\hline \multicolumn{6}{|c|}{ Muscle } \\
\hline $\mathrm{Tx}$ & & $4.8 \pm 0.3$ & $115.0 \pm 8.0^{2}$ & $320 \pm 33^{2}$ & $2.8 \pm 0.4$ \\
\hline $\mathrm{C}$ & & $5.3 \pm 0.4$ & $248.0 \pm 41.0$ & $538 \pm 81$ & $2.6 \pm 0.7$ \\
\hline
\end{tabular}

${ }^{2}$ Values recorded as mean and SEM; Tx: thyroidectomized animals $(n=5)$; C: control.

${ }^{2}$ Significant at $P<0.05$ level. 
decrease in the size of the limb epiphyseal centers, and a sclerotic appearance of the long bones.

Table 3 compares the total lipid concentration and the concentration of phospholipids, cholesterol, cerebrosides, and sulfatides in cerebrum and cerebellum of the thyroidectomized and control fetuses. The cerebral total lipid concentration was significantly decreased in the thyroidectomized fetuses $(4.04 \pm$ 0.19 versus $3.32 \pm 0.22, P<0.05$ ); however, there was no
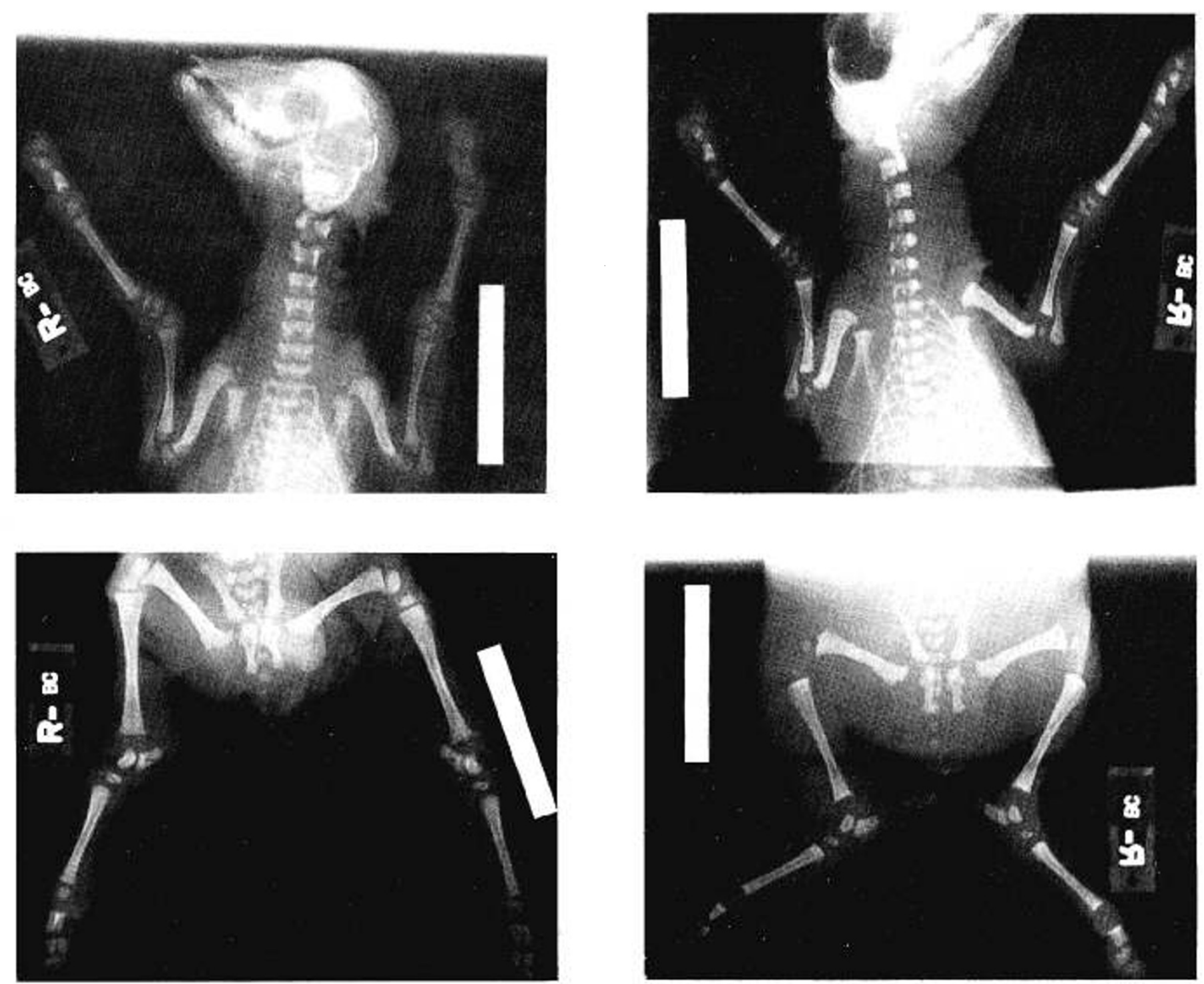

Fig. 4. Roentgenograms of lỉe extremities of a controí eutíngroiư ietus $(A)$ (left) and its thyroidectomized twin $(B)$ (right). The limb epiphyseal centers are decreased in size and the long bones have a sclerotic appearance in the thyroidectomized fetus.

Table 3. Lipid analysis of cerebral and cerebellar tissue of thyroidectomized and control ovine fetuses ${ }^{1}$

\begin{tabular}{|c|c|c|c|c|c|c|c|c|c|c|}
\hline & \multicolumn{5}{|c|}{ Cerebrum } & \multicolumn{5}{|c|}{ Cerebellum } \\
\hline & $\begin{array}{c}\text { Total } \\
\text { lipids, } \\
\text { \%wet wt }\end{array}$ & $\begin{array}{l}\text { Phospho- } \\
\text { lipids, } \\
\text { \%T.L. }\end{array}$ & $\begin{array}{l}\text { Choles- } \\
\text { terol, } \\
\text { \%T.L. }\end{array}$ & $\begin{array}{c}\text { Cerebro- } \\
\text { sides, } \\
\% \text { T.L. }\end{array}$ & $\begin{array}{l}\text { Sulfa- } \\
\text { tides, } \\
\% \text { T.L. }\end{array}$ & $\begin{array}{c}\text { Total } \\
\text { lipids, } \\
\text { \%wet wt }\end{array}$ & $\begin{array}{l}\text { Phospho- } \\
\text { lipids, } \\
\text { \%T.L. }\end{array}$ & $\begin{array}{l}\text { Choles- } \\
\text { terol, } \\
\text { \%T.L. }\end{array}$ & $\begin{array}{l}\text { Cerebro- } \\
\text { sides, } \\
\% \text { T.L. }\end{array}$ & $\begin{array}{l}\text { Sulfa- } \\
\text { tides, } \\
\% \text { T.L. }\end{array}$ \\
\hline \multicolumn{11}{|c|}{ Control $(\mathrm{n}=7)$} \\
\hline Mean & 4.04 & 62.9 & 17.5 & 2.17 & 2.03 & 5.87 & 61.3 & 22.3 & 1.14 & 0.43 \\
\hline SEM & 0.19 & 1.32 & 1.38 & 0.11 & 0.12 & 0.26 & 1.0 & 1.1 & 0.07 & 0.06 \\
\hline \multicolumn{11}{|c|}{$\begin{array}{l}\text { Thyroidectomized } \\
\qquad(n=5)\end{array}$} \\
\hline Mean & $3.32^{2}$ & 62.6 & 19.5 & 2.32 & 2.14 & 5.04 & 61.9 & 24.2 & 1.24 & 0.52 \\
\hline SEM & 0.22 & 1.95 & 1.18 & 0.29 & 0.19 & 0.30 & 3.1 & 2.1 & 0.17 & 0.08 \\
\hline
\end{tabular}

$1 \%$ T.L.: percentage of total lipids.

${ }^{2}$ Values significantly different, $P<0.03$. 
THYROIDECTOMIZED OVINE FETUS

Table 4. Cerebroside fatty acids from cerebellar tissue of thyroidectomized and control ovine fetuses

\begin{tabular}{|c|c|c|c|c|c|c|c|c|}
\hline & \multicolumn{8}{|c|}{ Fatty acid type ${ }^{1}$} \\
\hline & $16: 0$ & $16: 1$ & $18: 0^{2}$ & $18: 1^{3}$ & $20: 0$ & $22: 0$ & $24: 0$ & $24: 1$ \\
\hline \multicolumn{9}{|c|}{ Control $(n=7)$} \\
\hline Mean & 13.8 & 2.9 & 18.8 & 5.8 & 2.7 & 15.9 & 22.8 & 17.0 \\
\hline SEM & 1.4 & 0.4 & 1.1 & 0.6 & 0.3 & 1.0 & 1.5 & 1.1 \\
\hline \multicolumn{9}{|c|}{$\begin{array}{l}\text { Thyroidectomized } \\
\qquad(n=5)\end{array}$} \\
\hline Mean & 14.5 & 3.2 & 22.3 & 9.3 & 2.9 & 14.9 & 20.0 & 12.8 \\
\hline SEM & 1.9 & 0.9 & 1.2 & 1.0 & 0.3 & 1.8 & 1.6 & 1.9 \\
\hline
\end{tabular}

${ }^{1}$ Values recorded as percentage of total fatty acids.

${ }^{2}$ Values significantly different, $P<0.05$.

${ }^{3}$ Values significantly different, $P<0.01$.

significant difference between the two groups in the proportions of the individual lipid fractions. The total lipid content also was reduced, although not significantly, in cerebellar tissue of the thyroidectomized fetuses; again the proportions of the individual lipid components were similar in both groups.

Table 4 lists the fatty acid composition of cerebrosides in cerebellar tissue of thyroidectomized and control fetuses. The percentage of $\mathrm{C}_{18}$ fatty acids (stearic acid, 18:0, and oleic acid, 18:1) was significantly elevated in the thyroidectomized compared with the control fetuses; the percentage of $\mathrm{C}_{24}$ fatty acids (lignoceric acid, 24:0; and nervonic acid, 24:1) was lower in the athyrotic than in the control fetuses, but the difference was not significant $(P \cong 0.09)$.

\section{DISCUSSION}

After thyroidectomy, the ovine fetus rapidly becomes hypothyroid as evidenced by unmeasurable serum $T_{4}$ and $T_{3}$ levels 5 days after thyroidectomy $(0.7 \mu \mathrm{g} / 100 \mathrm{ml}$ and $<18$ $\mathrm{ng} / 100 \mathrm{ml}$, respectively) and elevated serum TSH concentrations $(300-1,500 \mu \mathrm{U} / \mathrm{ml}) 1$ month after thyroidectomy (14). Calculated net transfer of maternal thyroid hormones across the placenta amounted to only about $7 \%$ of the daily fetal iodothyronine turnover measured in the normal fetus (14). In similar studies Hopkins and Thorburn (24) also found very low levels of serum $\mathrm{T}_{4}$ in the thyroidectomized ovine fetus, and also have concluded that the ovine placenta is essentially impermeable to maternal $\mathrm{T}_{4}(23)$.

All of the thyroidectomized fetuses were at or below the 3rd percentile for weight. Although either one or two incisions were made into the uterus at the time of uterotomy, no more than 3 of the $40-50$ cotyledons normally present were lost during surgery and the loss of amniotic fluid was minimal. Thus placental blood flow and substrate supply to the fetus probably were not seriously affected, but measurements of these parameters were not conducted. In addition, all organ weights, except for the lungs, were similar in the thyroidectomized and control animals. The major reduction in weight was in the carcass, presumably including both muscle and bone. However, since we did not measure bone and muscle weights separately, it is not entirely clear whether the reduction in growth affected muscle or bone preferentially or whether both bone and muscle weights were reduced.

Both DNA and protein concentrations were reduced significantly in muscle tissue from the thyroidectomized fetuses and the protein to DNA ratio was normal (Table 2). These observations could be explained either by a decreased number of muscle cells, by an increased volume of muscle cell water, or both. Inasmuch as other tissues from the thyroidectomized fetuses demonstrated decreased protein in association with normal total DNA concentrations and RNA concentra- tions were normal in all tissues, it is unlikely that the total body water was increased in the thyroidectomized fetuses. Decreased protein concentration has been observed in muscle tissue of human cretins in association with a reduction in number of muscle cells $(8)$.

All other measured tissues of the thyroidectomized fetuses had DNA concentrations similar to control animals, which indicates that cell number was normal for age in these tissues. However, the protein concentration was reduced in several tissues, including cerebellum, heart, lung, thymus, and muscle of the thyroidectomized fetuses (Table 2). Although the protein to DNA ratio was reduced significantly only in the lung, the data suggest that cell size was reduced somewhat in all of these tissues. The marked reductions in weight, protein concentration, and protein to DNA ratio in lung tissue of the thyroidectomized fetuses suggest that growth of the ovine fetal lung is dependent on iodothyronines during the last trimester of gestation. Two recent reports have suggested that thyroxine may increase lung surfactant activity in rats and rabbits near term $(33,40)$, but surfactant activity was not investigated in the present study.

The present results are in agreement with data of Liggins and Kennedy (27) who noted a reduction in birth weight of ovine fetuses with electrocoagulated pituitary glands. Growth deficiency in such fetuses was most marked when the operation was performed early in pregnancy. The thyroid glands of these fetuses were smaller than those of control twin or triplet fetuses, but the extent of impairment of thyroid hormone and growth hormone secretions was not clear. Growth retardation also has been reported by Kerr et al. (25) in rhesus monkey fetuses made hypothyroid by ${ }_{13}{ }_{1}$ injections to the mother near midgestation. The skin changes in our fetuses were similar to those of Hopkins and Thorburn (24), who reported that thyroidectomy of the ovine fetus during the last trimester significantly impairs wool growth.

It is well known that iodothyronines are necessary for normal maturation of the CNS $(3,13,22,30,35,37)$. In the present study cerebral and cerebellar weights were similar in athyrotic and control animals, as were cerebral and cerebellar DNA concentrations. However, the protein concentration of cerebellar tissue in the athyrotic fetuses was reduced. There was a tendency to reduction in protein concentration in cerebral tissue as well, but this was not statistically significant. Thus brain weights and brain cell numbers were statistically normal in the thyroidectomized fetuses although there was the suggestion of a decrease in cerebellar cell size. Moreover, the reduction in total lipid concentration of cerebral tissue and the increase in cerebellar $C_{18}$ fatty acids associated with the tendency to decreased longer chain $\left(\mathrm{C}_{24}\right)$ fatty acids suggests that cerebellar myelination was significantly impaired in the hypothyroid fetuses. 
Barlow (4) has outlined in great detail the morphogenesis of the fetal ovine nervous system, dividing development into seven stages, with each region of the central nervous system having its own time table of development. In the cerebrum cell proliferation and differentiation begins between 40 and 70 days gestation and in the cerebellum between 47 and 80 days. Lipid importation, myelination, and maturation of myelin normally begin at about 70,100 , and 140 days, respectively, in the cerebellum (4). The observation in the present study of a slight reduction in cerebellar cell size, brain total lipid, and cerebellar myelination is consistent with the fact that fetal hypothyroidism was induced during the last trimester. Inasmuch as the ovine fetal thyroid begins to function at about 50 days gestation (5) and the fetuses were presumably euthyroid between 50 and $90-110$ days, the extent of thyroxine dependence of early ovine fetal brain development is not clear. However, the present data are in general agreement with an earlier report of Grippo and Menkes (21) which showed that fatty acid elongation was reduced in rats made hypothyroid at birth. These authors suggested that iodothyronines may stimulate the brain microsomal-fatty acid elongation system involved in the synthesis of saturated fatty acids characteristic for myelin lipids. Other studies in the hypothyroid neonatal rat also have demonstrated a decreased synthesis of myelin lipids (38).

Iodothyronines appear to stimulate protein synthesis in immature brain through an effect on RNA metabolism. Sokoloff (35), who studied the effects of thyroxine on infant rat brain mitochondria, suggested that the hormone produces a substance which enhances the transfer of soluble RNA-bound amino acid into microsomal protein. Gomez and coworkers (20) have shown that in a 10-day-old hypothryoid rat there is a depression of nuclear "rapidly labeled" and microsomal RNA in the brain; these results were assumed to be caused by altered transport of ribosomal RNA from the nucleus to microsomes. Recent data of Muzzo and Brasel (29), which indicates that thyroxine deficiency does not prevent but only delays cell growth and replication in newborn rat brain, may explain why some of these effects are reversible with therapy. In the human infant Klein et al. (26) have recently shown that very early treatment of hypothyroidism will minimize the degree of mental retardation.

Finally, the present study confirms that the fetal skeletal system is quite sensitive to iodothyronine deficiency during the last trimester of gestation. Thyroid hormone deficiency during this time results in delayed ossification of $\operatorname{limb}$ epiphyseal centers. Studies in hypothyroid fetal monkeys (25) and fetal sheep (24) have shown similar results. The mechanism for this delay is not entirely clear; it might be secondary, in part, to the relative decrease in body weight (19). Since all of the fetal ovine parathyroid glands are not located within the thyroid gland, the fetal thyroidectomy should not produce parathyroid hormone deficiency. A deficiency of thyrocalcitonin might be expected (32), but the role of this hormone in the fetus has not been studied. Because thyrocalcitonin does not cross the placenta (1) and fetal plasma levels of calcium and phosphorus were identical and greater than maternal levels in both athyrotic and euthyroid animals studied by Hopkins and Thorburn (24), it is doubtful that thyrocalcitonin plays a significant role in the skeletal changes seen in the athyrotic fetus. It is possible that growth hormone deficiency might impair fetal skeletal maturation and linear bone growth; however, growth hormone levels in athyrotic ovine fetuses have been shown to exceed values found in euthyroid controls (119 versus $60 \mathrm{ng} / \mathrm{ml})(24)$.

\section{SUMMARY}

Five ovine fetuses were thyroidectomized at 90-110 days gestation. Within 1 week post-thyroidectomy, serum $\mathrm{T}_{4}$ concentrations had fallen to $<0.7 \mu \mathrm{g} / 100 \mathrm{ml}$. Nineteen to 43 days post-thyroidectomy, the animals were killed and an autopsy performed. Mean body weight and lung weight were reduced significantly in the thyroidectomized fetuses, as contrasted with control animals. Mean DNA concentration was lower in muscle; the mean DNA to protein ratio was lower in lung, and the mean protein concentration was decreased in cerebellar, heart, lung, thymus, and muscle tissues of hypothyroid fetuses. The mean total lipid concentration was reduced in the cerebrum, and $\mathrm{C}_{18}$ cerebellar cerebroside fatty acids were relatively increased in the thyroidectomized fetuses. Finally, long bone epiphyseal centers were smaller and decreased in number in the athyrotic fetuses and the long bones had a sclerotic appearance.

These results suggest that thyroid hormone deficiency, present during the last trimester of intrauterine development of the ovine fetus, impairs carcass growth (probably by inhibiting cell replication), delays bone and skin maturation, inhibits growth in cell size in heart, lung, thymus, and cerebral tissues, and delays CNS myelination.

\section{REFERENCES AND NOTES}

1. Alexander, D. P., Britton, H. G., Nixon, D. A., Cameron, E., Fister, C. L., Buckle, R. M., and Smith, F. G., Jr.: Calcium, parath yroid hormone and calcitonin in the foetus. In: Foetal and Neonatal Physiology, p. 42 (Cambridge University Press, London, 1973).

2. Andersen, H. J.: Nongoitrous hy pothyroid ism. In : L. I. Gardner: Endocrine and Genetic Diseases of Childhood, pp. 216-234 (W. B. Saunders, Philadelphia, 1968).

3. Balazs, R.: Biochemical effects of thyroid hormones in the

developing brain. U.C.L.A. Forum Med. Sci., 14: $273(1971)$.
4. Barlow, R. M.: The foetal sheep: Morphogenesis of the nervous system and histochemical aspects of myelination. J. Comp. Neurol., 135: 249 (1969).

5. Barnes, C. M., Warner, D. E., Marks, S., and Bustad, L. K.: Thyroid function in fetal sheep. Endocrinology, 60: 425 (1968).

6. Bartlett, G. R.: Phosphorus assay in column chromatography. J. Biol. Chem., 234: 466 (1959).

7. Burton, K.: A study of the conditions and mechanisms of diphenylamine reaction for the colorimetric estimation of deox y ribonucleic acid. Biochem. J., 62: 315 (1956).

8. Cheek, D. B.: Muscle cell growth in abnormal children. In: D. Cheek: Hum an Growth: Body Composition, Cell Growth, Energy and Intelligence, p. 369 (Lea \& Febiger, Philadelphia, 1968).

9. Chopra, I. J.: A radioimmunoassay for measurement of thy roxine in unextracted serum. J. Clin. Endocrinol. Metab., 34: 938 (1972).

10. Chopra, I. J., Ho, R. S., and Lam, R.: An improved radioimmunoassay for triiodothyronine in serum: Its application to clinical and physiologic studies. J. Lab. Clin. Med., 80: 729 (1972).

11. Dussault, J. H., Hobel, C. J., DiStefano, J. J., III, Erenberg, A., and Fisher, D. A.: Triiodothyronine turnover in maternal and fetal sheep. Endocrinology, 90: 1301 (1972).

12. Dussault, J. H., Hobel, C. J., and Fisher, D. A.: Maternal and fetal thyroxine secretion during pregnancy in the sheep. Endocrinology, 88: 47 (1971).

13. Eayrs, J. T.: Influence of the thyroid on the central nervous system. Brit. Med. Bull., 16: 122 (1960).

14. Erenberg, A., Omori, K., Oh, W., and Fisher, D. A.: The effect of fetal thyroidectomy on thyroid hormone metabolism in maternal and fetal sheep. Pediat. Res., 7: 870 (1973).

15. Evitar, L., Harris, D. R., and Menkes, J. H.: Diffuse sclerosis and Addison's disease: Biochemical studies of gray matter, white matter and myelin. Biochem. Med., 8: 268 (1973).

16. Faryna de Raveglia, I., Gomez, C. J., and Ghittoni, N. E.: Hormonal regulation of brain development. V. Effect of neonatal thyroidectomy on lipid changes in cerebral cortex and cerebellum of developing rats. Brain Res., 43: 181 (1972).

17. Fisher, D. A., Hobel, C. J., Garza, R., and Pierce, C. A.: Thyroid function in the preterm fetus. Pediatrics, 46: 208 (1970).

18. Friede, R. L., and Hu, K. H.: Increase in cholesterol along human optic nerve. J. Neurochem., 14: 307 (1967).

19. Geloso, J. P., Hemon, P., Legrand, J., Legrand, C., and Jost, A.: Some aspects of thyroid physiology during the perinatal period. Gen. Comp. Endocrinol., 10: 191 (1968).

20. Gomez, C. J., Duvilanski, B. H., Soto, A. M., and De Guglielmore, A. E. R.: Hormonal regulation of brain development. VI. Kinetic studies of the incorporation in vivo of $\left({ }^{3} \mathrm{H}\right)$ orotic acid into RNA of brain subcellular fractions of 10-day-old normal and hy pothy-

roid rats. Brain Res., 44: 231 (1972).
21. Grippo, J., and Menkes, J. H.: Effect of thyroid on fatty acid biosynthesis in brain. Pediat. Res., 5: 466 (1971). 
22. Hamburger, M.: The role of thyroid and growth hormones in neurogenesis. Current Top. Develop. Biol., 4: 109 (1969).

23. Hopkins, P. S., and Thorburn, G. D.: Placental permeability to maternal thyroxine in sheep. J. Endocrinol., 49: 549 (1971).

24. Hopkins, P. S., and Thorburn, G. D.: The effects of foetal thyroidectomy on the development of the ovine fetus. J. Endocrinol., 54: 55 (1972).

25. Kerr, G. R., Tyson, I. B., Allen, J. R., Wallace, J. H., and Scheffler, G.: Deficiency of thyroid hormone and development of the fetal Rhesus monkey. I. Effect on physical growth, skeletal maturation and biochemical measures of thyroid function. Biol. Neonate, $21: 282$ (1972).

26. Klein, A. H., Meltzer, S., and Kenny, F. M.: Improved prognosis in congenital hypothyroidism treated before three months. J. Pediat., 81: 912 (1972)

27. Liggins, G. C., and Kennedy, F. C.: Effects of electrocoagulation on the foetal lamb hypophysis on growth and development. J. Endocrinol., 40: 371 (1968).

28. Lowry, O. H., Rosebrough, N. J., Farr, A. L., and Randall, R. J.: Protein measurement with the Folin phenol reagent. J. Biol. Chem., 198: 265 (1951).

29. Muzzo, S. J., and Brasel, J.: Neonatal hypothyroidism and DNA synthesis in rat cerebellum. Program of the 55th Meeting of the Endocrine Society, June 1973, p. A155 (Abstract 214).

30. Myant, N. B.: On the possible role of the thyroid in the control of the development of the mammalian brain. Biol. Neonate, 9: 148 (1966).

31. Omori, K., Oh, W., Emmanouilides, G. C., Erenberg, A., and Hobel, C. J.: Intrauterine somatic growth in sheep. In preparation.

32. Patel, A. J., and Balazs, R.: Effect of thyroid hormone on metabolic compartmentation in the developing rat brain. Biochem. J., 121: 469 (1971).

33. Redding, R. A., Douglas, W. H. J., and Stein, M.: Thyroid hormone influence upon lung surfactant metabolism. Science, 175: 994 (1972).

Copyright $\odot 1974$ International Pediatric Research Foundation, Inc.
34. Reichlin, S., Martin, J. B., Boshans, R. L., Schalch, D. S., Pierce, J, G., and Bollinger, J.: Measurement of TSH in plasma and pituitary of the rat by radioimmunoassay utilizing bovine $\mathrm{TSH}$ : Effect of thyroidectomy or thyroxine administration on plasma TSH levels. Endocrinology, 8 7: 1022 (1970).

35. Sokoloff, L.: Action of thyroid hormones and cerebral development. Amer. J. Dis. Child., 114: 498 (1967).

36. Stein, R. A., Slauson, V., and Mead, J. F.: Gas-liquid chromatography of fatty acids and derivatives. In: G. V. Marinetti: Lipid Chromatographic Analysis, pp. 361 (Marcel Dekker, New York, 1967).

37. Szijou, I., Kalbermann, L. E., and Gomez, C. J.: Hormonal regulation of brain development. IV. Effect of neonatal thyroidectomy upon incorporation in vivo of $\mathrm{L}-\left({ }^{3} \mathrm{H}\right)$ phenylalanine in proteins of developing rat cerebral tissues and pituitary gland. Brain Res., 27: 309 (1971).

38. Walravens, P., and Chase, H. P.: Influence of thyroid on formation of myelin lipids. J. Neurochem., 16: 1477 (1969).

39. Webb, J. M.: A sensitive method for the determination of ribonucleic acid in tissue and microorganisms. J. Biol. Chem., 221: 635 (1956).

40. Wu, B., Kikkawa, Y., Orzalesi, M. M., Motoyama, E. K., Kaibera, M. Zingas, C. J., and Cook, D. D.: Accelerated maturation of fetal rabbit lungs by thyroxine. Physiologist, 14: 253 (1971).

41. We are grateful to Donald Harris, Robert Lam, Sherri Ho, and Bonnie Privett for technical assistance and to Sharyn Shaw for preparation of the manuscript.

42. This research was supported by United States Public Health Service Grants nos. HD-04720 and NB-06938 from the National Institutes of Child Health and Human Development and the National Institute of Neurological Diseases and Blind ness.

43. Requests for reprints should be addressed to: D. A. Fisher, M.D., Harbor General Hospital, 1000 W. Carson St., Torrance, Calif. 90509.

44. Accepted for publication April 26, 1974.

Printed in U.S.A.

\title{
Fibrin-stabilizing Factor (Factor XIII) in the Fetus and the Newborn Infant
}

\author{
P. HENRIKSSON, U. HEDNER, I. M. NILSSON, J. BOEHM, B. ROBERTSON, AND L. LORAND ${ }^{(30)}$ \\ Coagulation Laboratory, University of Lund, Allmänna sjukhuset, Malmö, Sweden, Evanston Hospital and \\ Department of Biochemistry and Molecular Biology, Northwestern University, Evanston, Illinois, USA
}

\section{Extract}

Using a fluorescent method based on the ability of the thrombin and calcium-activated fibrin-stabilizing factor (factor XIII) to incorporate dansyl cadaverine into casein, measurements were made in plasma samples from 52 healthy neonates and 25 fetuses between the 17th and 24th gestational weeks. Forty healthy adults and 63 samples from pregnant women were used as controls. The measured values ranged from 3 to 21 units $/ \mathrm{ml}$ of plasma for neonates and 1 to 14 for fetuses, compared with 7 to 42 for the adult normal and 3 to 15 for the pregnant women populations.

\section{Speculation}

It is conceivable that the relatively low fibrin-stabilizing factor activity during fetal life and immediately after birth, corresponding, respectively, to mean values of about 0.25 and
0.5 of that found in normal adults, may afford some safeguard against lasting coagulation damage.

In recent years much interest has been focused on fibrin-stabilizing factor (FSF or factor $X I I I$ ), the plasma zymogen of the transamidating enzyme responsible for the covalent cross-linking of fibrin molecules during clotting. Its chemical properties (for review see Reference 8 ) and variations of the plasma levels of the factor in different pathologic conditions have been the subject of several studies (e.g., 11, $13,18,19,22)$. For newborn infants, some authors reported low values $(1,3,7,23)$, whereas others have found normal adult levels $(6,14,17,21,24)$. However, all of these investigations were carried out with bioassays, such as differential clot solubilities, which from the quantitative point of view are of questionable reliability. 